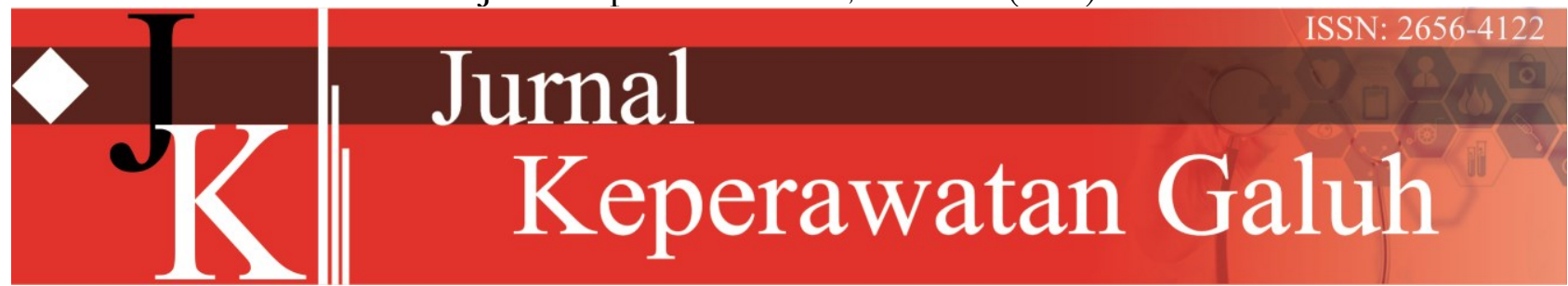

https://jurnal.unigal.ac.id/index.php/JKG/article/view/4082

\title{
STUDI KOMPARATIF PENGGUNAAN ALAT PERMAINAN EDUKATIF JENIS SANDPLAY DAN PUZZLE TERHADAP PERKEMBANGAN MOTORIK HALUS ANAK USIA PRASEKOLAH
}

\author{
Erni Yuniati \\ Akademi Keperawatan Setih Setio Muara Bungo, Indonesia \\ (Sejarah artikel: Diserahkan Mei 2020, Diterima Juni 2020, Diterbitkan Juli 2020)
}

\begin{abstract}
ABSTRAK
Menurut WHO, 5-25\% anak usia prasekolah mengalami gangguan perkembangan motorik halus. Perkembangan motorik halus anak salah satunya dipengaruhi oleh penggunaan alat permainan edukatif. Terdapat dua jenis permainan edukatif yang digunakan dalam menstimulus perkembangan motorik halus anak diantaranya adalah pasir (sandplay) dan puzzle. Namun sayangnya dilapangan, kegiatan yang dapat menstimulus perkembangan motorik halus anak masih belum dilakukan dengan adekuat, dalam hal ini frekuensinya masih kurang dari yang digunakan. Sehingga perkembangan motorik halus anak menjadi kurang optimal. Tujuan penelitian ini untuk mengetahui studi komparatif penggunaan alat permainan edukatif jenis pasir (sandplay) dan puzzle terhadap perkembangan motorik halus anak usia prasekolah di Taman Kanak-Kanak at Taqwa Mekarsari, Cimahi Jawa Barat. Penelitian ini menggunakan metode penelitian quasi experiment design dengan rancangan pretest dan posttest. Teknik pengambilan sampel menggunakan purposive sampling sejumlah 34 responden terdiri atas 2 kelompok yaitu 17 responden kelompok intervensi permainan edukatif jenis pasir (sandplay) dan 17 responden kelompok intervensi permainan edukatif jenis puzzle. Penilaian menggunakan lembar instrumen DENVER II yang diambil aspek pengukuran motorik halus. Analisa data yang digunakan adalah uji t 2 sampel dependen dan uji t 2 sampel independen untuk bivariat. Hasil penelitian membuktikan bahwa tidak terdapat perbedaan yang signifikan antara intervensi permainan edukatif jenis pasir (sandplay) dan puzzle terhadap perkembangan motorik halus anak. Berdasarkan hasil penelitian, untuk menstimulus perkembangan motorik halus anak, agar dilakukan dengan menambah frekuensi permainan, dapat menggunakan pasir (sandplay) dan puzzle atau jika kesulitan menyediakan keduanya, dapat menggunakan salah satu saja, pasir (sandplay) atau puzzle saja.
\end{abstract}

Kata Kunci: Perkembangan motorik halus, stimulus sandplay , stimulus puzzle

\section{PENDAHULUAN}

Pembangunan kesehatan sebagai bagian dari upaya membangun manusia seutuhnya antara lain diselenggarakan melalui upaya kesehatan anak yang dilakukan sedini mungkin. Salah satu intervensi yang dapat dilakukan yaitu meningkatkan perkembangan anak. Intervensi perkembangan anak dapat dilakukan menurut tahapan usia (Soetjiningsih, 2012). Tahap-tahap perkembangan anak meliputi neonatus, bayi, todler, usia prasekolah dan usia sekolah (Soetjiningsih, 2012).

Seorang anak dapat mengalami keterlambatan perkembangan pada hanya satu ranah perkembangan saja, tetapi dapat pula di lebih dari satu ranah perkembangan. Masalah ranah perkembangan yang sering terjadi pada anak usia dini/ prasekolah adalah perkembangan motorik halus (Ikatan Dokter Anak Indonesia, 2013). Perkembangan motorik halus tidak terlepas dari anak usia prasekolah, karena motorik halus berkaitan dengan kemampuan anak melakukan kegiatan yang melibatkan koordinasi mata dan tangan seperti memegang krayon, menulis, yang merupakan kemampuan dasar yang harus dimiliki oleh anak usia prasekolah. Dampak yang terjadi apabila kurangnya pencegahan gangguan perkembangan motorik halus pada anak akan menyebabkan perkembangannya tidak sesuai dengan umur (Sa'amah, 2012). Solusi yang dapat dilakukan untuk mencegah terjadinya gangguan perkembangan motorik halus pada anak yaitu 
dengan melakukan deteksi dini tumbuh kembang anak dan skrining serta orang tua memberikan stimulasi lebih awal

Motorik halus merupakan kegiatan melakukan gerakan yang melibatkan bagian-bagian tubuh tertentu saja dan dilakukan otot-otot kecil, tetapi memerlukan koordinasi yang cermat. Misalnya kemampuan untuk menggambar dan memegang sesuatu benda (Wong, 2009).

World Health Organizations (WHO, 2009), melaporkan bahwa 5-25\% dari anak-anak usia prasekolah menderita disfungsi otak minor, termasuk gangguan perkembangan motorik halus (Widati, 2012). Sedangkan berdasarkan data dari Depkes RI (2006) menunjukkan bahwa 0,4 juta atau sekitar $16 \%$ usia prasekolah di Indonesia mengalami gangguan perkembangan. UNICEF (2005) bahwa masih tingginya angka kejadian gangguan pertumbuhan dan perkembangan pada anak usia balita khususnya gangguan perkembangan motorik yaitu sekitar 27,5\%/ 5 juta anak mengalami gangguan. Hal ini terjadi dipicu oleh kurangnya deteksi dini dan kurangnya stimulasi yang diberikan untuk mendukung perkembangan motorik halus (Widati, 2012).

Menurut Hurlock (2007), perkembangan motorik halus menjadi bagian yang tidak terpisahkan dalam kehidupan anak usia prasekolah.

Anak usia prasekolah merupakan bagian dari anak usia dini yang berada pada rentang usia lahir sampai 6 tahun dan fase ini merupakan usia emas (golden age). Seperti yang dikemukakan oleh Piaget, karena pada usia ini anak memiliki peranan penting untuk mengembangkan berbagai potensi (Depdiknas, 2006).

Untuk mengetahui tahap perkembangan anak diperlukan deteksi dini tumbuh kembang (DDTK). Deteksi dini pada anak prasekolah dilakukan dengan menggunakan Kuisioner Pra Skrining Perkembangan (KPSP)/ DDST. KPSP/ DDST dapat dilakukan oleh tenaga kesehatan (Dokter, Bidan dan Perawat) sesuai dengan standar yang ada (Depkes RI, 2010).

Faktor yang mempengaruhi perkembangan anak usia prasekolah salah satunya adalah bermain. Bermain adalah cara yang paling berharga, melalui bermain, anak akan menggunakan sensor motorik atau fungsionalnya, bermain dapat merangsang kecerdasan, indra dan emosi, mengembangkan imajinasi, kreativitas anak (Wong, 2009). Salah satu teknik dalam metode bermain adalah permainan, karena teknik permainan menciptakan suatu suasana santai dan menyenangkan, membuat seseorang dapat belajar lebih baik (Wong, 2009).

Terdapat banyak jenis permainan yang dapat digunakan dalam mengasah kemampuan motorik halus anak usia prasekolah, hasil beberapa penelitian diantaranya terdapat beberapa metode permainan yang digunakan untuk meningkatkan kemampuan motorik halus anak, dari beberapa permainan tersebut peneliti memilih pasir dan puzzle karena selain keduanya mudah didapat, kelebihan bermain pasir adalah banyak anak-anak yang menyukai pasir, pasir juga bertekstur lembut yang enak dipegang dan digenggam oleh anak kecil, bahan pasir bersifat multiguna karena mudah diubah bentuknya kebentuk lain melalui aktivitas membentuk menggunakan berbagai cetakan yang dapat melatih otot-otot dan syaraf taktil anak. Bermain pasir dapat mengasah keterampilan motorik halus dengan melatih gerakan otot-otot jari, dan syaraf taktil anak, pergelangan tangan yang membutuhkan koordinasi mata dan tangan, kecepatan, ketepatan telapak dan jari yang sangat diperlukan untuk mengembangkan kemampuan menulis permulaan pada anak usia prasekolah (Rubianti, 2013).

Menurut penelitian Nirmalasari, Mulyani dan Utami (2013), puzzle selain mudah didapat, juga merupakan permainan yang sudah tidak asing lagi bagi anak, sering dipakai untuk anak usia prasekolah. Puzzle merupakan salah satu bentuk permainan yang mampu mengasah kemampuan berpikir, mempermudah anak dalam mengingat dan memahami konsep-konsep, anak menjadi lebih kreatif dan manfaat bermain puzzle lainnya adalah berdampak pada perkembangan kognitif anak. Dalam bermain puzzle, anak dituntut bernalar sehingga otak anak akan terasah.

Hasil penelitian Rufaida (2013), tentang Penerapan Bermain Pasir Untuk Meningkatkan Kemampuan Motorik Halus Pada Anak Kelompok A TK Yunior Surabaya menunjukkan bahwa penerapan bermain pasir telah mampu meningkatkan kemampuan motorik halus anak kelompok A TK Yunior Surabaya. Penelitian tersebut dilakukan selama satu bulan, teknik pengumpulan data dalam penelitian ini adalah observasi. Jumlah sampel dalam penelitian tersebut adalah 20 orang.

Menurut Medirisa et all (2015), Selain permainan pasir (sandplay), ada juga permainan jenis puzzle, yang dapat dijadikan alternatif yang aman dan efektif meningkatkan kemampuan motorik halus pada anak prasekolah.

Fenomena pemberian stimulasi dini terhadap anak usia dini atau usia prasekolah saat ini dinilai sedikit menurun yaitu terdapat aspek perkembangan motorik halus yang kurang menjadi fokus yang ingin dicapai, padahal aspek motorik halus merupakan aspek sangat penting pada anak usia prasekolah. Dalam hal ini disebabkan guru/ terapis ataupun orang tua terfokus pada tingkat pencapaian perkembangan kemampuan kognitif 
dan bahasa anak. Selain itu juga sesuai dengan tuntutan wali murid yang mengharapkan semua anak yang telah lulus dari TK mampu membaca dan berhitung dengan lancar (Rufaida, 2013).

Pada tahun pertama, sering kali tenaga kesehatan dan orang tua lebih memfokuskan pada perkembangan motorik kasar saja (Ardana et al, 2015). Hal ini menyebabkan perkembangan motorik yang dianggap normal tersebut dengan suatu harapan yang semu terhadap kemampuan intelektual anak. Kemampuan intelektual anak dapat dilihat pada perkembangan bahasa dan pemecahan masalah, selain itu perhatian kurang diberikan pada perkembangan motorik halus. Padahal perkembangan motorik halus merupakan indikator yang lebih baik (lebih dapat menilai kemampuan motorik anak) daripada motorik kasar, dalam diagnosis gangguan motorik pada anak (Ardana et al, 2015).

Data dari Dinas Kesehatan Kota Cimahi, didapatkan data Tahun 2012 dari 2409 anak yang dilakukan pemeriksaan perkembangan terdapat 9,6\% (231) anak yang mengalami penyimpangan. Tahun 2014 dari 2277 yang dilakukan pemeriksaan perkembangannya didapatkan $3,9 \% \quad(90$ anak terdiri dari 52 laki-laki dan 38 perempuan) yang mengalami penyimpangan. Tahun 2016 (selama 2 bulan) menunjukkan dari jumlah anak 3031 yang diperiksa perkembangannya didapatkan sebanyak 1,7\% (52 anak terdiri dari 37 laki-laki dan 15 perempuan) yang mengalami penyimpangan perkembangan.

Taman Kanak-Kanak (TK) merupakan salah satu lembaga pendidikan untuk anak usia dini yang memberikan pelayanan dalam bidang pendidikan dibawah Unit Pelaksana Dinas Pendidikan. Berdasarkan studi pendahuluan yang dilakukan oleh peneliti pada bulan Februari 2016 di TK At Taqwa dari hasil wawancara yang dilakukan bahwa terdapat anak yang perkembangannya belum optimal terutama aspek motorik halus belum mencapai yang diinginkan. Data yang didapatkan menunjukkan bahwa sekitar $40 \%$ anak belum dapat melaksanakan tugas perkembangan sesuai dengan usianya pada aspek motorik halus. Hal tersebut berdampak anak dapat mengalami keterlambatan perkembangan motorik halus atau perkembangan motorik halusnya tidak sesuai dengan usia, anak hanya dapat melakukan kegiatan motorik halus dibawah usia perkembangannya.

Hasil penelitian Ariyana (2008), mengenai perkembangan anak yang abnormal karena disebabkan oleh faktor lingkungan pengasuhan, status gizi, status kesehatan, stimulasi, dan budaya (Hidayat, 2008). Hasil penelitian Puspitasari dan Hasibuan (2013), tentang meningkatkan keterampilan motorik halus anak melalui kegiatan menggambar diatas pasir di kelompok A-2 TK Dharma Wanita Blooto Kota Mojokerto, dari data didapatkan bahwa masalah yang terdapat pada anak di TK tersebut sebanyak 37,5\% anak bermasalah dengan kemampuan motorik halus, terjadi peningkatan kemampuan motorik halus anak di TK Dharma menjadi 94\% setelah dilakukan permainan menggambar diatas pasir.

Masih terdapatnya data yang menunjukkan anak yang mengalami perkembangan motorik halus tidak normal, hal ini jika tidak ditangani akan menjadi masalah bagi anak kaitannya dengan kemampuan motorik halus, anak tidak dapat melakukan tugas perkembangan motorik halus sesuai usia, anak hanya mampu melakukan tugas perkembangan dibawah usianya, karena perkembangan motorik halus pada usia dini yang tidak optimal. Berkaitan dengan hal tersebut jelaslah bahwa anak harus terus dkembangkan secara optimal agar dapat mencapai kondisi yang sebaik-baiknya dimasa yang akan datang. Oleh karena itu, stimulasi perkembangan motorik halus misalnya pemberian alat permainan edukatif menjadi hal yang sangat penting bagi perkembangan anak pada usia dini.

Mengingat kondisi dan hambatan tersebut, perlu dilakukan pengembangan terhadap kemampuan motorik halus anak agar memiliki kemampuan motorik halus yang lebih baik. Hasil kajian peneliti, dan beberapa jurnal penelitian terdahulu yaitu Rufaida (2013) di Surabaya, peneitian Medirisa (2015) di Boyolali dan penelitian Setyaningsih (2014) di Kebumen, Jawa Tengah, terdapat beberapa gaps yang muncul seperti masih bervariasinya durasi waktu atau waktu pelaksanaan intervensi pemberian terapi bermain pasir (sandplay) dan puzzle, ada yang 2 minggu (14 hari), ada yang 4 minggu (1 bulan) dan ada juga yang 6 minggu (1,5 bulan). Selain itu, terkait penelitian Nirmalasari, Mulyani dan Utami (2013) yang menjelaskan tentang manfaat puzzle dapat meningkatkan perkembangan kognitif anak. Berdasarkan hal tersebut penulis sangat tertarik untuk mengadakan penelitian membandingkan permainan edukatif pasir (sandplay) dan puzzle dengan menambah atau menyamakan durasi waktu untuk kedua terapi bermain dengan alat permainan edukatif yang terkait dengan Studi Komparatif Penggunaan Alat Permainan Edukatif Jenis Pasir (Sandplay) Dan Puzzle Terhadap Perkembangan Motorik Halus Anak Usia Prasekolah.

\section{METODE PENELITIAN}

Penelitian ini menggunakan rancangan penelitian quasi eksperimen dengan menggunakan 
Jurnal Keperawatan Galuh, Vol.2 No.2 (2020) 65 - 70

desain pretest dan posttest. Untuk mengukur pretest dan posttest menggunakan uji t dimana uji $\mathrm{t}$ 2 sampel dependen digunakan untuk melihat apakah ada pengaruh pretest dan posttest pada kelompok intervensi yang diberikan permainan sandplay dan puzzle. Sedangkan uji t 2 sampel independen digunakan untuk melihat apakah terdapat perbedaan hasil posttest motoric halus kelompok intervensi sandplay dan puzzle.

Populasi pada penelitian ini adalah anak usia prasekolah TK berjumlah 85 orang. Teknik pengambilan sampel dalam penelitian ini menggunakan Purpossive sampling yaitu metode pemilihan sampel yang dilakukan berdasarkan maksud atau tujuan tertentu yang ditentukan oleh peneliti. Sampel dalam penelitian ini adalah anak prasekolah dengan kriteria inklusi. Berdasarkan perhitungan sampel minimal menurut Sugiyono (2012) dan berdasarkan perhitungan rumus sampel maka didapatkan sampel yaitu 17 orang diberikan perlakuan permainan puzzle, dan 17 orang diberikan permainan sandplay. Jadi total sampel minimal yang dibutuhkan adalah 34 anak usia prasekolah.

Penelitian dilakukan selama 1 (satu) bulan, penilaian menggunakan lembar kuisioner biodata anak usia prasekolah, lembar/ instrumen untuk melihat perkembangan motorik halus anak prasekolah (modifikasi dari Denver II aspek motorik halus) dan prosedur penggunaan alat permainan edukatif sandplay dan puzzle. Analisa data yang digunakan adalah analisa univariat dan bivariate dengan uji t-test.

\section{HASIL PENELITIAN}

Rerata perkembangan motorik halus anak sebelum dan setelah diberikan permainan edukatif jenis pasir (sandplay)

Tabel 1

Rerata perkembangan motorik halus anak sebelum dan setelah diberikan permainan edukatif jenis pasir (sandplay)

\begin{tabular}{ccccc} 
Variabel & Mean & SD & Minimal-Maksimal & $\mathbf{9 5 \% C I}$ \\
\hline Pretest & 3,35 & 0,493 & $3-4$ & $3,10-3,61$ \\
Posttest & 1,94 & 0,659 & $1-3$ & $1,60-2,28$
\end{tabular}

Berdasarkan tabel 1 dengan memperhatikan hasil pada pretest dan posttest intervensi permainan edukatif jenis pasir (sandplay) didapatkan nilai rata-rata pretest 3,35, (95\% CI $=3,10-3,61)$ dengan $\mathrm{SD}$ 0,493, nilai pretest terendah 3 dan tertingi 4 . Dari hasil estimasi intervensi disimpulkan bahwa $95 \%$ diyakini bahwa rerata perubahan perkembangan motorik halus anak sebelum intervensi permainan edukatif jenis pasir (sandplay) adalah antara 3,10 sampai dengan 3,61. Sedangkan pada hasil posttest intervensi permainan edukatif jenis pasir (sandplay) didapatkan nilai rata-rata posttest 1,94, (95\% CI $=1,60-2,28)$ dengan SD 0,659 , nilai posttest terendah 1 dan tertinggi 3. Dari hasil estimasi intervensi disimpulkan bahwa 95\% diyakini bahwa rata-rata posttest perkembangan motorik halus anak dengan kelompok intervensi permainan edukatif jenis pasir (sandplay) adalah antara 1,60 sampai dengan 2,28. Dari hasil estimasi interval disimpulkan bahwa $95 \%$ diyakini selisih rerata peningkatan perkembangan motorik halus anak sebelum dan setelah intervensi permainan edukatif jenis pasir (sandplay) adalah antara 1,5 sampai dengan 1,33.

\section{Rerata perkembangan motorik halus anak sebelum dan setelah diberikan permainan edukatif jenis puzzle.}

Tabel 2

Rerata perkembangan motorik halus anak sebelum dan setelah diberikan permainan edukatif jenis puzzle

\begin{tabular}{ccccc} 
Variabel & Mean & SD & Minimal-Maksimal & $95 \%$ CI \\
\hline Pretest & 3,35 & 0,493 & $3-4$ & $3,10-3,61$ \\
Posttest & 1,88 & 0,600 & $1-3$ & $1,57-2,19$
\end{tabular}


Berdasarkan tabel 2 dengan memperhatikan hasil distribusi nilai pada pretest intervensi permainan edukatif jenis puzzle didapatkan rata-rata pretest 3,35, (95\% CI $=3,10-3,61)$ dengan SD 0,493, nilai skor terendah 3 dan tertinggi 4 . Dari hasil estimasi interval disimpulkan bahwa 95\% diyakini bahwa rata-rata pretest perkembangan motorik halus anak dengan kelompok intervensi permainan edukatif puzzle adalah antara 3,10 sampai dengan 3,61. Sedangkan hasil distribusi nilai pada posttest setelah intervensi permainan edukatif jenis puzzle didapatkan rata-rata 1,88, $(95 \% \mathrm{CI}=1,57-2,19)$ dengan SD 0,600, nilai skor terendah 1 dan tertinggi 3. Dari hasil estimasi interval disimpulkan bahwa 95\% diyakini bahwa rata-rata posttest perkembangan motorik halus anak dengan kelompok intervensi permainan edukatif puzzle adalah antara 1,57 sampai dengan 2,19. Dari hasil estimasi interval disimpulkan bahwa 95\% diyakini bahwa selisih rerata peningkatan perkembangan motorik halus anak sebelum dan setelah intervensi permainan edukatif jenis puzzle adalah antara 1,53 sampai dengan 1,42.

\section{Analisis perbedaan penggunaan alat permainan edukatif jenis pasir (sandplay) dan puzzle terhadap perkembangan motorik halus anak usia prasekolah}

Hasil uji perbedaan posttest anak antara kedua kelompok intervensi disebut juga uji t 2 sampel independen dapat dijelaskan pada tabel 4.5 sebagai berikut :

Tabel 3

Hasil uji analisis perbedaan penggunaan alat permainan edukatif jenis pasir (sandplay) dan puzzle terhadap perkembangan motorik halus

\begin{tabular}{cccccc} 
Variabel & Mean & SD & SE & P value & N \\
\hline Posttest sandplay & 1,94 & 0,659 & 0,160 & 0,787 & 17 \\
Posttest Puzzle & 1,88 & 0,600 & 0,146 & & 17
\end{tabular}

Berdasarkan tabel 3 didapatkan bahwa rata-rata perkembangan motorik halus posttest sandplay adalah 1,94 dengan standar deviasi 0,659 , sedangkan rata-rata perkembangan motorik halus pada posttest puzzle adalah 1,88 dengan standar deviasi 0,600 . Hasil uji statistik didapatkan nilai $\mathrm{p}=0,787$ berarti pada alpha $5 \%$ terlihat tidak ada perbedaan yang signifikan rata-rata perkembangan motorik halus antara anak yang diberikan permainan edukatif jenis pasir (sandplay) dan anak yang diberikan permainan jenis puzzle.

\section{SIMPULAN}

Rerata perkembangan motorik halus anak sebelum dan setelah diberikan permainan edukatif jenis pasir (sandplay) terjadi peningkatan perkembangan motorik halus yang signifikan terlihat adanya peningkatan rata-rata kemampuan motorik halus anak, dilihat dari nilai rata-rata sebelum diberikan permainan edukatif jenis pasir (sandplay) yaitu 3,35 menjadi meningkat setelah diberikan permainan edukatif jenis pasir (sandplay) yaitu 1,94 .

Rerata perkembangan motorik halus anak sebelum dan setelah diberikan permainan edukatif jenis puzzle terjadi peningkatan perkembangan motorik halus yang signifikan terlihat adanya peningkatan rata-rata kemampuan motorik halus anak, dilihat dari nilai rata-rata sebelum diberikan permainan edukatif jenis puzzle yaitu 3,35 menjadi meningkat setelah diberikan permainan edukatif jenis puzzle yaitu 1,88 .

Perbedaan penggunaan alat permainan edukatif jenis pasir (sandplay) dan puzzle terhadap perkembangan motorik halus pada kedua kelompok intervensi didapatkan hasil bahwa tidak terdapat perbedaan yang signifikan antara kedua kelompok intervensi pasir (sandplay) dan puzzle. Dari hasil penelitian posttest antara permainan edukatif jenis pasir (sandplay) dan puzzle didapatkan nilai p yaitu 0,787 berati pada alpha $5 \%$ terlihat tidak ada perbedaan yang signifikan ratarata perkembangan motorik halus antara anak yang diberikan permainan edukatif jenis pasir (sandplay) dengan anak yang diberikan permainan edukatif jenis puzzle. 


\section{DAFTAR PUSTAKA}

Hidayat, A.A. (2005). Pengantar ilmu keperawatan anak 1. Jakarta: Salemba Medika.

Indrianawati, F., dan Hasibuan, R. 2013. Pengaruh aktivitas bermain Pasir Terhadap kemampuan sosio-emosional anak kelompok B di TK Anissa Bangah, GedanganSidoarjo.

Medirisa, L.P., Susilo, D.J., dan Aniroh, U. (2015). Pengaruh pemberian stimulus permainan puzzle terhadap perkembangan motorik halus anak usia 4-6 tahun di Taman KanakKanak Aisyiyah Krasak, Teras, Boyolali.

Nirmalasari, D., Mulyani, B., dan Utami, B. (2013). Studi komparasi penggunaan media mind map dan crossword puzzle pada metode proyek ditinjau dari kreativitas siswa terhadap prestasi belajar pada materi pokok system koloid kelas xi semester genap SMA N 1 Banyudono. 2 (4).

Rubianti, R., Thamrin, M., dan Yuniarni, D. (2013). Peningkatan keterampilan sosial melalui permainan pada anak usia 4-5 tahun, Universitas Tanjungpura, Pontianak. 3.

Rufaida, N., dan Reza, M. (2013). Penerapan bermain pasir untuk meningkatkan kemampuan motorik halus pada anak kelompok A TK Yunior Surabaya.

Sa'amah, U (2012). tersedia http://umisaamah.blogspot.co.id/2012/07/pe ndekatan-dan-metode-pembelajarandi_07.html, diakses 07 Maret 2016.

Soetjiningsih dan Ranuh, G. (2013). Tumbuh kembang anak. Jakarta: EGC.

Sugiyono. (2014). Statistik untuk penelitian. Bandung: Alfabeta CV.

Setyaningsih, S. (2014), Pengaruh penggunaan alat permainan edukatif jenis puzzle terhadap perkembangan anak usia prasekolah di Taman Kanak-Kanak Aisyiyah Pertanahan Kebumen, Jawa Tengah, Tesis, Jawa Tengah, Stikes Jenderal Achmad Yani.

Wong, D. (2009). Buku ajar keperawatan pediatrik. Jakarta: EGC. 